\title{
SP Gas Well Development Strategy at Offshore B Flowstation Using Analytical Hierarchy Process
}

\author{
Septian Cahya ${ }^{1}$ and Nurhadi Siswanto ${ }^{2}$ \\ ${ }^{1}$ Department of Technology Management, Institut Teknologi Sepuluh Nopember, Surabaya \\ ${ }^{2}$ Department of Industrial and Systems Engineering, Institut Teknologi Sepuluh Nopember, Surabaya \\ e-mail: siswanto@ie.its.ac.id
}

\begin{abstract}
This research is focused on analyzing strategies for developing SP well production in the B Flowstation offshore platform. The development in question is the construction of platforms and SP gas well production facilities based on the application of the SP gas well production operation mode to the existing Bravo Flowstation production system. The application of the SP well production operation mode will determine the design of the production facility and the amount of investment the company has to operate the SP well. The mode of production operation also affects the continuity and stability of SP gas well production in meeting the company's production targets. Based on seismic results and studies from the company that wells have capacity of 53.5 BCF with a gas production rate of $30 \mathrm{MMSCFD}$ and is capable of producing for 6 years. Incorrect application of operating modes has the potential to cause premature production, which means that production from the well cannot last for 6 years. That is because the occurrence of water coning which has an impact on gas production is hindered by the rate of water production. In addition, the application of the operation mode also affects the continuity of gas well production. Gas production activities may be halted due to production shutdowns due to a mismatch of the SP well production line technology design that is applied to an existing production system. The cessation of SP well gas production activities can also be caused by operational activities such as maintenance activities. From the potential problems that arise, a qualitative analysis is needed by considering every aspect of the problem. With the complexity of things that must be considered in the production development strategy used the AHP (Analytic Hierarchy Process) method. 4 alternative choices of SP well operation modes are determined by the expert. The alternatives include: high pressure mode; low pressure mode; medium pressure mode; and combine high low pressure mode. Criteria identified by the expert include: technology; capital costs; the impact of existing production; operating costs; decline reservoir. From the data obtained in the field as a reference for experts to determine the weighting in the AHP method, the dominant alternative is the development of SP wells based on the combining high low pressure operation mode. The high low pressure operating mode provides continuous production without being affected by existing production processes and has the potential for a medium for water coning. With a sizeable investment the SP well development strategy can be on target in production and on return on investment.
\end{abstract}

Keywords-Operating Mode, AHP, On Target; On Return.

\section{INTRODUCTION}

B USINESS changes and developments are very dynamic. No exception for businesses in the upstream oil and gas industry. Changing markets are marked by fluctuations in world oil prices until the discovery of new technology makes the oil and gas industry must be able to adapt. Upstream oil and gas schemes or business models can change so that the industrial landscape will also move dynamically. In January 2017 the Ministry of Energy and Mineral Resources released the Minister of Energy and Mineral Resources Regulation (Permen) No. 8 of 2017 concerning gross split revenue sharing contracts.

B flowstation is an offshore platform in the working area of an oil and gas company which stretches from the west of the thousand islands to the coast of Indramayu. In 2017, it will run a project to increase gas production through the development of gas production from SP wells that have been drilled in 2012. Based on the results of seismic and bottom hole pressure surveys in the reservoir, that wells have capacity of 53.5 BCF and wells are able to flow production of 30 MMSCFD. B flowstation has a fairly complex gas production process, the integration of SP well production in the existing production process that is not appropriate has the potential to cause production problems that can result in the cessation of the production process of SP wells and existing wells. The development of SP well gas production includes the construction of a production facility infrastructure that is used to flow gas production from the reservoir to the $\mathrm{B}$ flowstation. The development of SP well production is based on the operation of well pressure. The well can be operated in high, medium and low pressure modes. Inappropriate operation of wells has the potential to cease well production due to the phenomenon of water coning, namely the closure of gas flow by water production in reservoirs (Kermit $\mathrm{E}$ Brown, vol 4). Operating pressure will also determine the amount of investment costs incurred by the company and the amount of operating costs incurred by the company during production.

\section{A. Problem}

How to determine the mode of production operation by considering multiple aspects, both from the life time of the well, investment costs, operational costs, risks, and the sustainability of production from SP wells.

These problems have a correlation from previous research related to multi criteria decisions such as: "Multi-criteria selection of electric power plants using analytical hierarchy processes" (Bilal A. Akash, 1999), namely for the selection of suitable power plants developed in Jordan. There are several alternative power plants including fossil fuel power plants, solar power plants, nuclear power plants, wind power plants and hydroelectric power plants. Determination of choice is based on the cost cost - benefit ratio. Then it has also been applied in research "Using a multi-method approach for decision-making about a sustainable local distributed energy 
The $6^{\text {th }}$ International Seminar on Science and Technology (ISST) 2020

July $25^{\text {th }} 2020$, Institut Teknologi Sepuluh Nopember, Surabaya, Indonesia

system: A case study from Finland" (Sanni Väisänen, 2016). thermal energy for the distribution of energy systems which

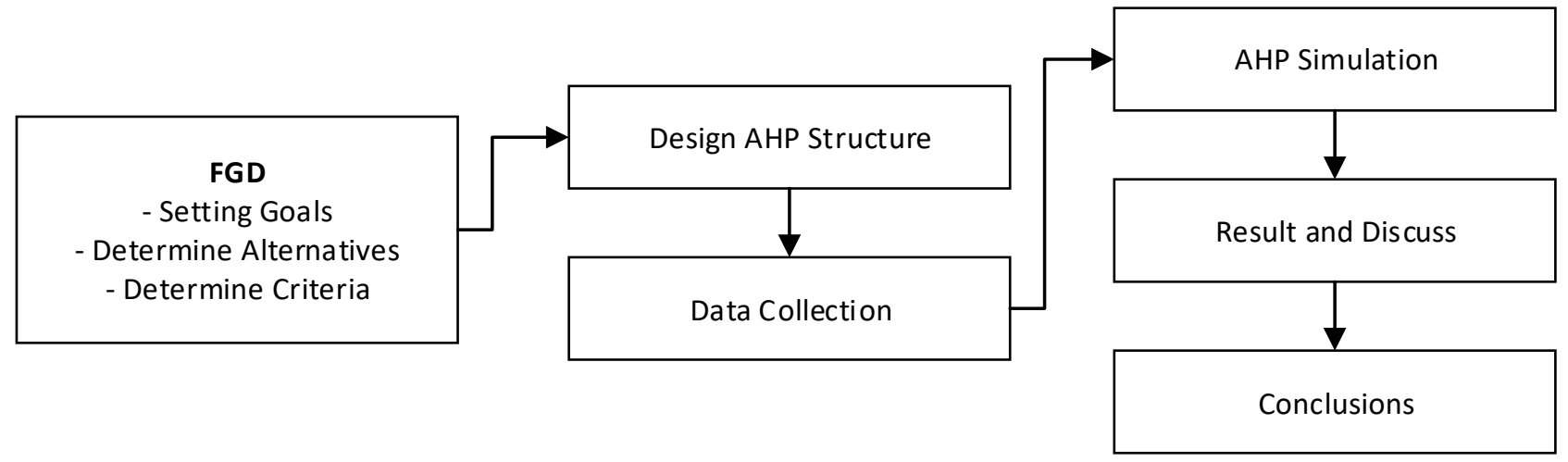

Figure 1. Flow Chart of Method.

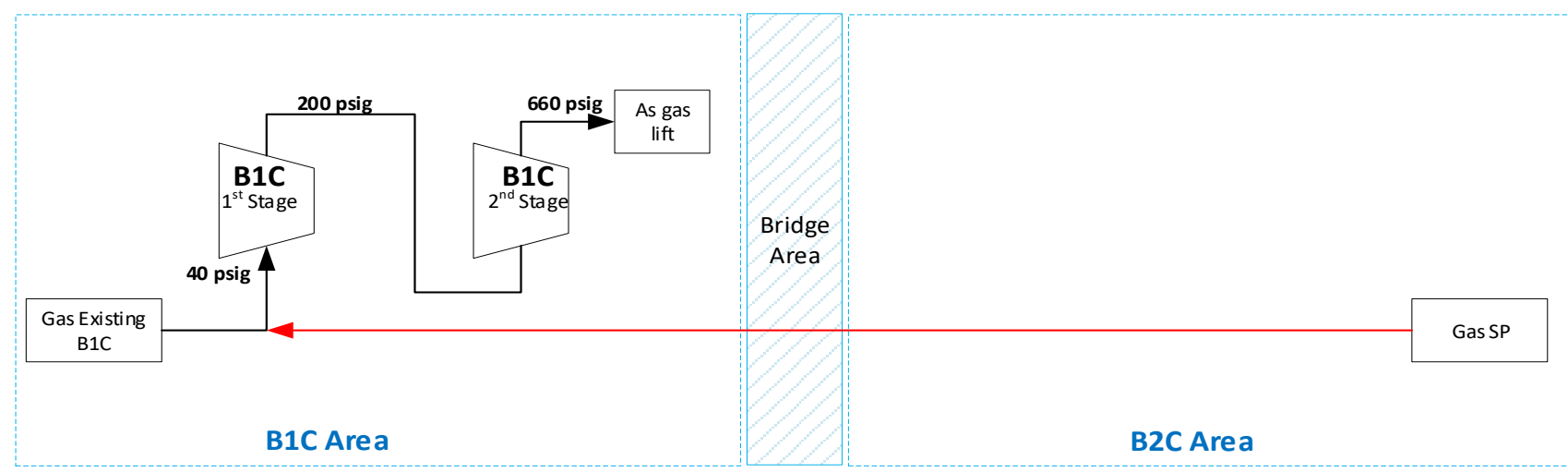

Figure 2. Design of Alternative low pressure operation mode.

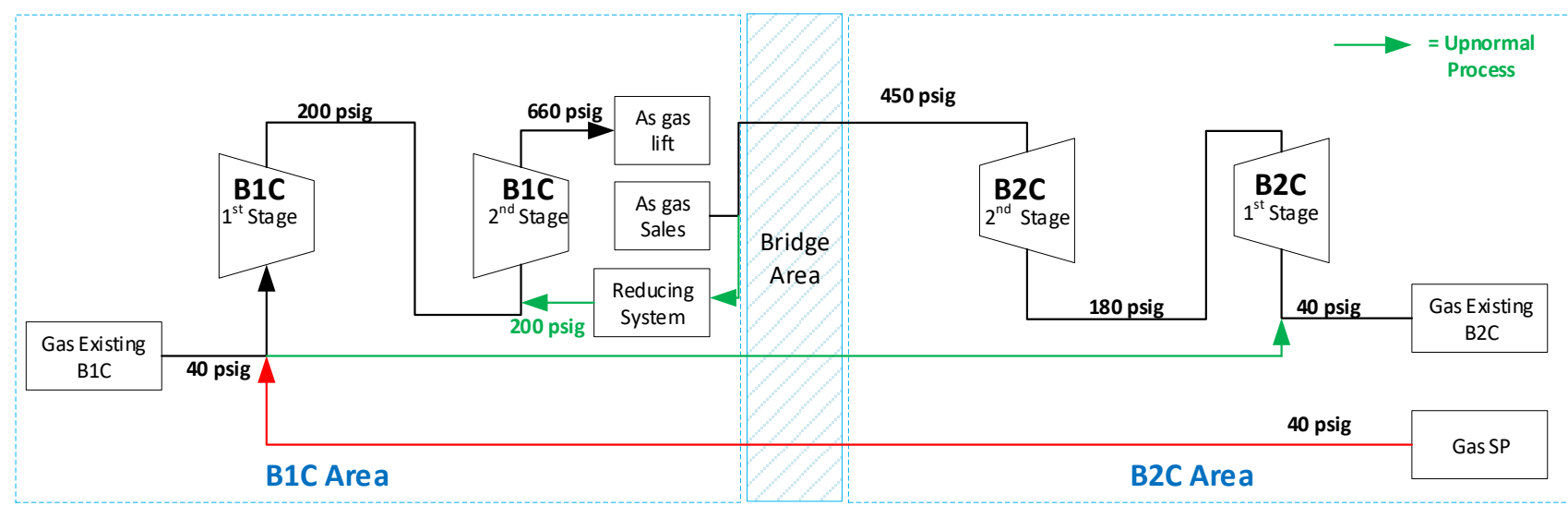

Figure 3. Desain of Alternative medium pressure operation mode.

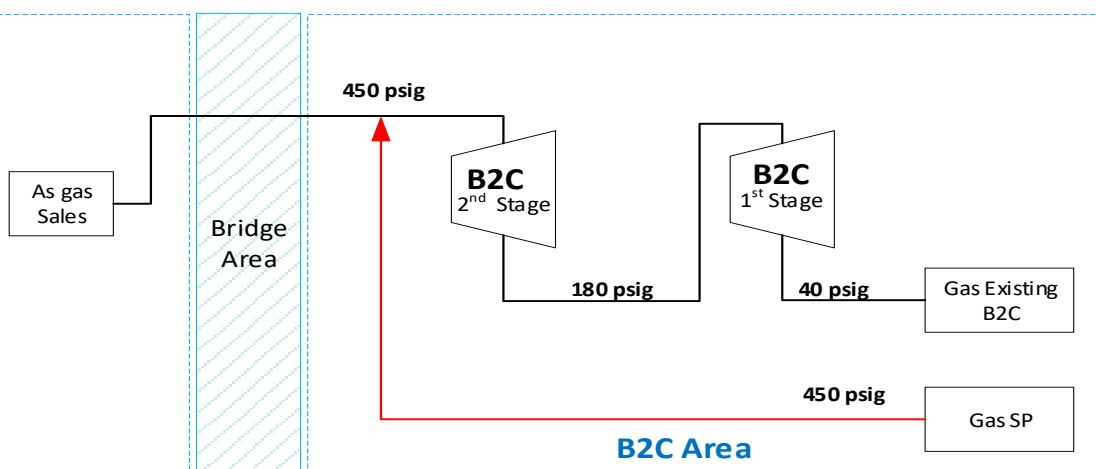

Figure 4. Desain of Alternative high pressure operation mode.

In a study conducted by Sanni, AHP combined with LCA (life cycle assessment) is used to assess the sustainability of three energy scenarios, namely non-biomass energy of hydropower and wind power, combined solar energy, and combined solar is sustainable in Finland. From some of these studies prove that AHP is a relevant method for solving problems in multicriteria decision making, including in determining the appropriate mode of operation in SP well development. 
The $6^{\text {th }}$ International Seminar on Science and Technology (ISST) 2020

July $25^{\text {th }} 2020$, Institut Teknologi Sepuluh Nopember, Surabaya, Indonesia

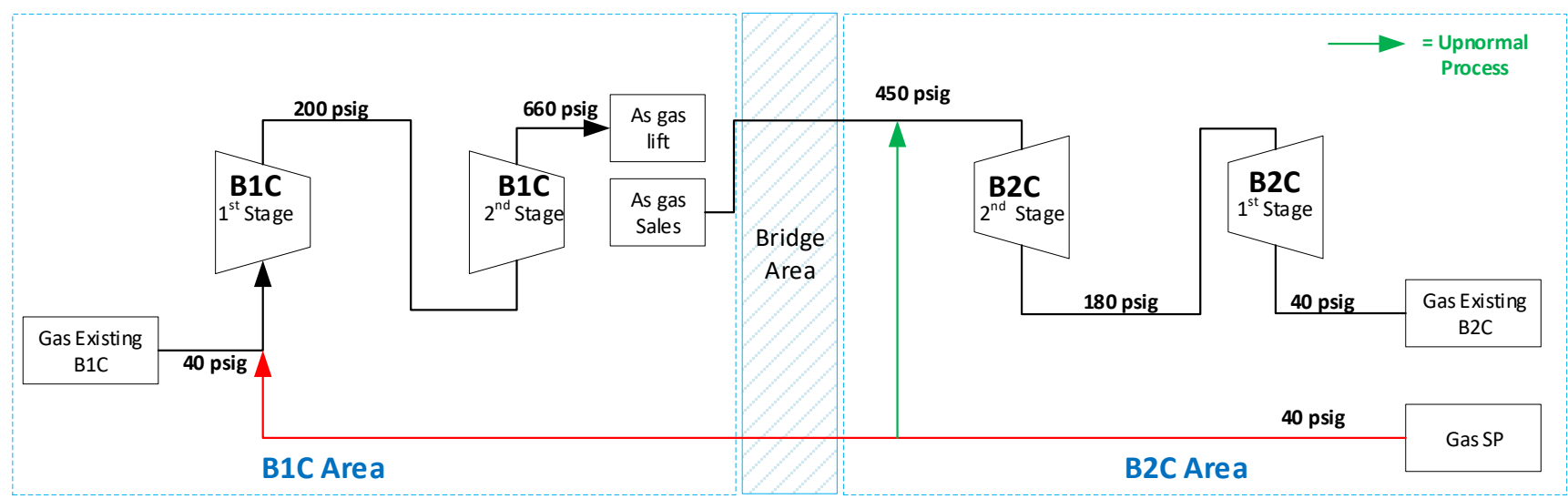

Figure 5. Design of Alternative high low pressure operation mode.

Table 1.

Criteria and sub criteria

\begin{tabular}{ccc}
\hline \hline No & Criteria & Sub Criteria \\
\hline & & Maintenance level \\
Design \\
1 & Technology & Material readiness for combine another project \\
& Compressor performance \\
2 & Capital cost & \\
3 & Potential loss production & \\
4 & Operational cost & HSSE \\
5 & Reservoir & Time \\
6 & Installation & Shutdown tie in \\
\hline \hline
\end{tabular}

Figure 6. AHP structure.

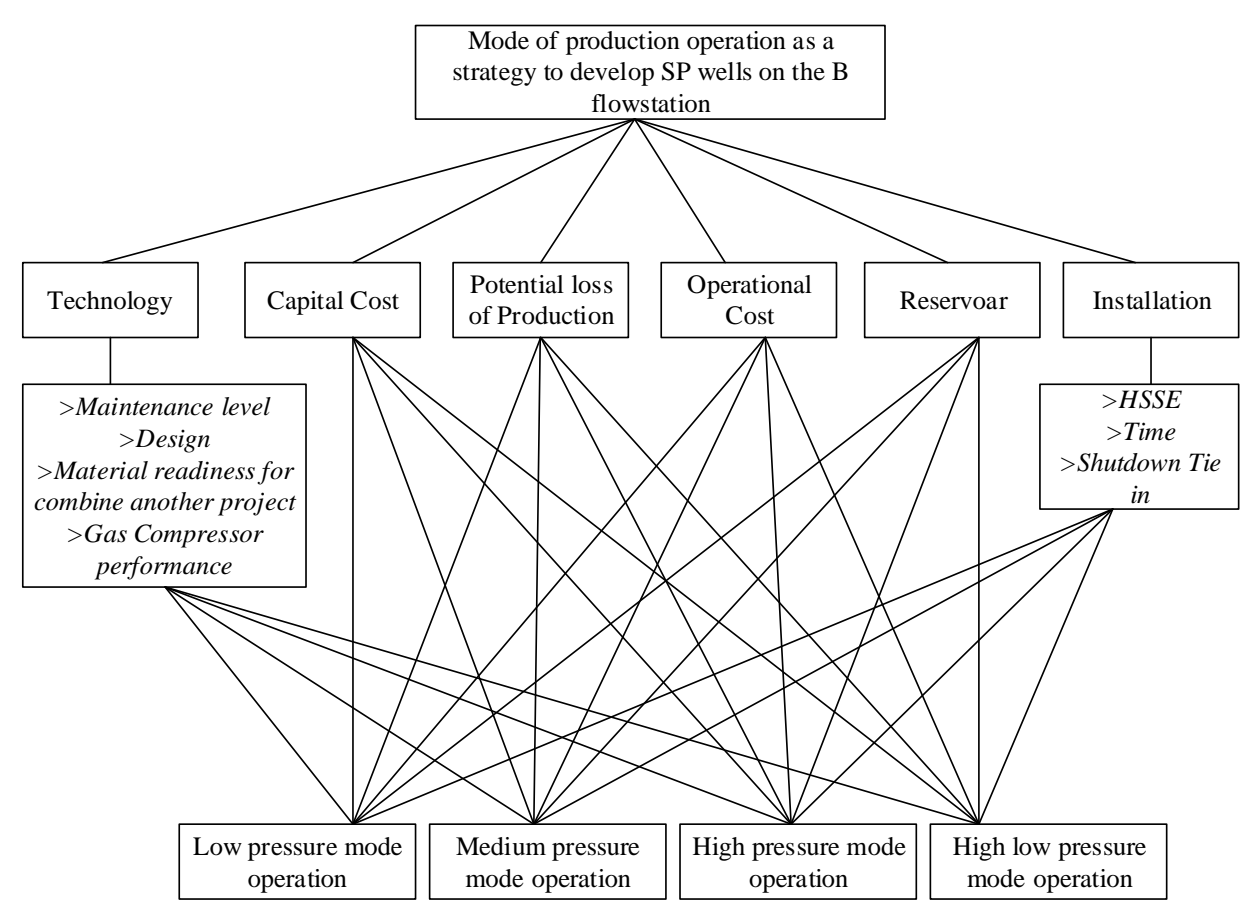

\section{METHOD}

In determining the mode of production operation of SP wells, a focus group discussion is conducted in the early stages of brainstorming about the design of SP well production processes that may be applied to existing systems. Furthermore, a field survey was conducted as material to continue the design discussion in the focus group discussion. In accordance with Figure 1, finally there were four alternative choices of operating modes for SP well production.

\section{A. Alternative of operating modes for SP wells production}

\section{1) Low pressure operation mode}

In Figure 2, the low pressure operation mode, gas production from the SP well will be received at the production facility that will be built in the SP well development project. The gas is then flowed into the B1C 
The $6^{\text {th }}$ International Seminar on Science and Technology (ISST) 2020

July $25^{\text {th }}$ 2020, Institut Teknologi Sepuluh Nopember, Surabaya, Indonesia

Table 2.

Design advantages

\begin{tabular}{llcccc}
\hline \hline No & \multicolumn{1}{c}{ Description } & $\begin{array}{c}\text { Low pressure } \\
\text { operation mode }\end{array}$ & $\begin{array}{c}\text { Medium pressure } \\
\text { operation mode }\end{array}$ & $\begin{array}{c}\text { High pressure } \\
\text { operation mode }\end{array}$ & $\begin{array}{c}\text { High low pressure } \\
\text { operation mode }\end{array}$ \\
\hline \multirow{2}{*}{1} & Design & & & & \\
& a.Redundant Process Line & No & Yes & No & Yes \\
& b.accommodate until gas production runs out & Yes & Yes & No & Yes \\
\hline \hline
\end{tabular}

Table 3.

Material review

\begin{tabular}{clccc}
\hline \hline No & Description & $\begin{array}{c}\text { Low pressure } \\
\text { operation mode }\end{array}$ & $\begin{array}{c}\text { Medium pressure } \\
\text { operation mode }\end{array}$ & $\begin{array}{c}\text { High pressure } \\
\text { operation mode }\end{array}$ \\
\hline 2 & $\begin{array}{l}\text { Material readiness for combine } \\
\text { another project }\end{array}$ & No, low rating & Yes, medium rating & Yes, high rating \\
operation mode
\end{tabular}

Table 4.

Compressor performance

\begin{tabular}{|c|c|c|c|c|c|c|}
\hline No & Description & $\begin{array}{c}\text { Low pressure } \\
\text { operation mode }\end{array}$ & \multicolumn{2}{|c|}{ Medium pressure operation mode } & $\begin{array}{l}\text { High pressure } \\
\text { operation mode }\end{array}$ & $\begin{array}{c}\text { High low } \\
\text { pressure } \\
\text { operation mode } \\
\end{array}$ \\
\hline \multirow{11}{*}{3} & Compressor performance & & & & & \\
\hline & Flowing to compressor & Yes & & & No & Yes/No \\
\hline & SG gas SP & 0.5868 & & & 0.5868 & 0.5868 \\
\hline & SG gas existing & $\mathrm{B} 1 \mathrm{C}=0.8866$ & $\mathrm{~B} 1 \mathrm{C}=0.8866$ & $\mathrm{~B} 2 \mathrm{C}=0.8462$ & - & $\mathrm{B} 1 \mathrm{C}=0.8866$ \\
\hline & SG gas blending & $\mathrm{B} 1 \mathrm{C}=0.7736$ & $\mathrm{~B} 1 \mathrm{C}=0.7736$ & $\mathrm{~B} 2 \mathrm{C}=0.7489$ & - & $\mathrm{B} 1 \mathrm{C}=0.7736$ \\
\hline & Efficiency compressor existing & $\mathrm{B} 1 \mathrm{C}=73 \%$ & $\mathrm{~B} 1 \mathrm{C}=73 \%$ & $\mathrm{~B} 2 \mathrm{C}=77 \%$ & - & $\mathrm{B} 1 \mathrm{C}=73 \%$ \\
\hline & NGP existing & $\mathrm{B} 1 \mathrm{C}=92.8 \%$ & $\mathrm{~B} 1 \mathrm{C}=92.8 \%$ & $\mathrm{~B} 2 \mathrm{C}=92.5 \%$ & - & $\mathrm{B} 1 \mathrm{C}=92.8 \%$ \\
\hline & NPT existing & $\mathrm{B} 1 \mathrm{C}=63.8 \%$ & $\mathrm{~B} 1 \mathrm{C}=63.8 \%$ & $\mathrm{~B} 2 \mathrm{C}=94.7 \%$ & - & $\mathrm{B} 1 \mathrm{C}=63.8 \%$ \\
\hline & Efficiency compressor blend SP & $\mathrm{B} 1 \mathrm{C}=73 \%$ & $\mathrm{~B} 1 \mathrm{C}=72 \%$ & $\mathrm{~B} 2 \mathrm{C}=78 \%$ & - & $\mathrm{B} 1 \mathrm{C}=73 \%$ \\
\hline & NGP blend SP & $\mathrm{B} 1 \mathrm{C}=94.4 \%$ & $\mathrm{~B} 1 \mathrm{C}=93.8 \%$ & $\mathrm{~B} 2 \mathrm{C}=93.5 \%$ & - & $\mathrm{B} 1 \mathrm{C}=94.4 \%$ \\
\hline & NPT blend SP & $\mathrm{B} 1 \mathrm{C}=95.7 \%$ & $\mathrm{~B} 1 \mathrm{C}=94.2 \%$ & $\mathrm{~B} 2 \mathrm{C}=98.9 \%$ & - & $\mathrm{B} 1 \mathrm{C}=95.7 \%$ \\
\hline
\end{tabular}

Table 5.

Activities that could potentially cause loss of production

\begin{tabular}{|c|c|c|c|c|c|}
\hline No & Activities & $\begin{array}{c}\text { Low pressure } \\
\text { operation mode }\end{array}$ & $\begin{array}{c}\text { Medium pressure } \\
\text { operation mode }\end{array}$ & $\begin{array}{l}\text { High pressure } \\
\text { operation mode }\end{array}$ & $\begin{array}{c}\text { High low pressure } \\
\text { operation mode }\end{array}$ \\
\hline \multirow{5}{*}{1} & Maintenance Turbine gas Compressor & YES & 1 & 1 & $\mathrm{NO}$ \\
\hline & b. PM 1000 Hours & YES & No & No & No \\
\hline & c. PM 8000 Hours & YES & NO & NO & NO \\
\hline & d. Engine Change Out & YES & NO & NO & NO \\
\hline & e. Stripping Down & YES & NO & $\mathrm{NO}$ & $\mathrm{NO}$ \\
\hline 2 & Turnaround/TAR & YES & YES & $\mathrm{NO}$ & $\mathrm{NO}$ \\
\hline 3 & Shutdown Bpro (Oil and gas processing) & YES & YES & $\mathrm{NO}$ & $\mathrm{NO}$ \\
\hline 4 & Shutdown B1C Compressor & YES & $\mathrm{NO}$ & $\mathrm{NO}$ & $\mathrm{NO}$ \\
\hline 5 & Shutdown B2C Compressor & $\mathrm{NO}$ & $\mathrm{NO}$ & $\mathrm{NO}$ & NO \\
\hline 6 & Shutdown SP wells & YES & YES & YES & YES \\
\hline
\end{tabular}

Table 6.

Reservoir review

\begin{tabular}{cccccc}
\hline \hline \multirow{2}{*}{ No } & Description & $\begin{array}{c}\text { Low pressure } \\
\text { operation mode }\end{array}$ & $\begin{array}{c}\text { Medium pressure } \\
\text { operation mode }\end{array}$ & $\begin{array}{c}\text { High pressure } \\
\text { operation mode }\end{array}$ & $\begin{array}{c}\text { High low pressure } \\
\text { operation mode }\end{array}$ \\
\hline 1 & Life time of Reservoir & 6 years & 6 years & 3 years & 4 years \\
2 & Potential of water coning & low & medium & High & medium \\
\hline \hline
\end{tabular}

Table 7.

Sub criteria of installation review

\begin{tabular}{llcccc}
\hline \hline No & Description & $\begin{array}{c}\text { Low pressure } \\
\text { production } \\
\text { operation mode }\end{array}$ & $\begin{array}{c}\text { Medium pressure } \\
\text { production } \\
\text { operation mode }\end{array}$ & $\begin{array}{c}\text { High pressure } \\
\text { production } \\
\text { operation mode }\end{array}$ & $\begin{array}{c}\text { High low pressure } \\
\text { production } \\
\text { operation mode }\end{array}$ \\
\hline 1 & HSSE- Risk Job (Installation) & 50 & 60 & 30 & 60 \\
2 & Time (installation) & 3 Month & 5 Month & 3 Month & 5 Month \\
3 & Duration of Shutdown Tie in & 12 Hours & 12 Hours & 9 Hours & 12 Hours \\
\hline \hline
\end{tabular}

compression system at a pressure of 40 psig through a pipe under the bridge that connects $\mathrm{B} 1 \mathrm{C}$ and $\mathrm{B} 2 \mathrm{C}$. Gas production from SP wells is integrated with existing $\mathrm{B} 1 \mathrm{C}$ process gas and compressed to a pressure of 660 psig as a gas lift.

\section{2) Medium pressure operation mode}

Desain of Alternative medium pressure operation mode are shown in Figure 3.

\section{3) High pressure operation mode}

Desain of Alternative high pressure operation mode are shown in Figure 4.

\section{4) High low pressure operation mode}

In the medium pressure operating mode shown in Figure 3, when normal the SP gas well production process will be operated as a low pressure operating mode. When there is an 
The $6^{\text {th }}$ International Seminar on Science and Technology (ISST) 2020

July $25^{\text {th }} 2020$, Institut Teknologi Sepuluh Nopember, Surabaya, Indonesia

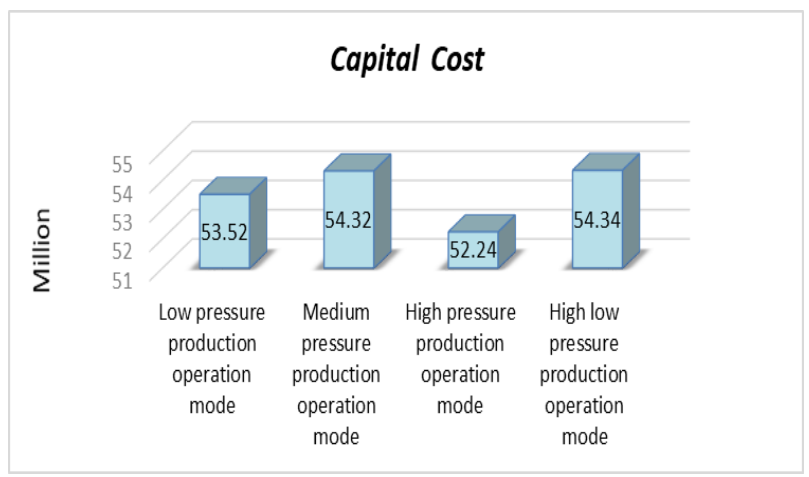

Figure 7. Capital cost estimation.

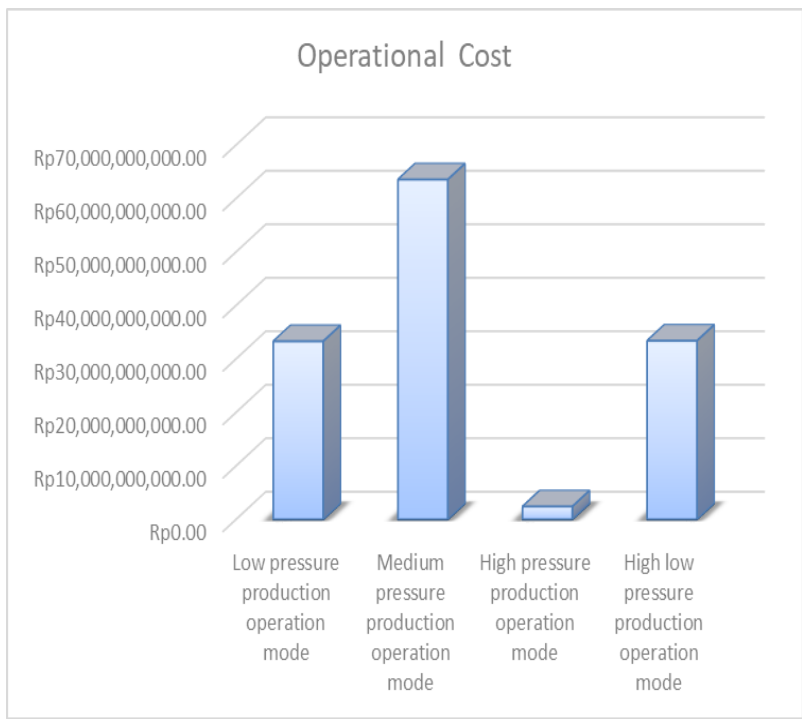

Figure 8. Operational cost estimation.

upset process or maintenance on the first stage B1C compressor, gas from the SP along with the existing $\mathrm{B} 1 \mathrm{C}$ process gas is directed to the $\mathrm{B} 2 \mathrm{C}$ compressor with a pressure of 40 psig. The gas is mixed with the existing B2C process gas. then the gas will be flowed as gas sales and some of the gas will be flowed to the second stage B1C compressor to be used as a gas lift.

In the high pressure operation mode shown in Figure 4, SP well gas production will be received at the production facility that will be built in the SP well development project. The next gas is directly flowed into the sales channel as gas sales with a pressure of $450 \mathrm{psig}$. Whereas in the high low pressure operating mode shown in Figure 5, when the normal gas process will be operated as a low pressure operating mode. When an upset and maintenance process occurs, the compressor B1C gas from sp well will be operated as a high pressure operating mode.

\section{B. Criteria}

Criteria are formed from focus group discussions. These criteria are formed based on aspects that must be considered in a production development project. These criteria are also aligned with the company's target so that the alternative chosen is in line with company expectations. The criteria are as follows which shown in Table 1.

\section{AHP Structure}

AHP structure are shown in Figure 6.

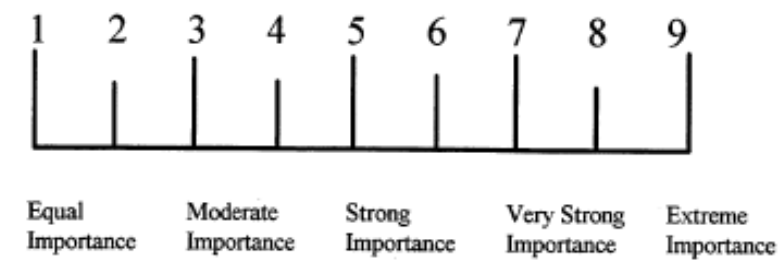

Figure 9. Saaty pairwise comparison scale.

\section{Data collection}

\section{1) Maintenance level}

Based on the risk matrices of maintenance activities, it is predicted that maintenance activities from each alternative with medium to high risk levels are as follows:

a. Low pressure operation mode 34 activities

b. Medium pressure operation mode 41 activities

c. High pressure operation mode 32 activities

d. High low pressure operation mode 36 activities

2) Design

Design advantages are shown in Table 2.

3) Material readiness for combine another project

Material review are shown in Table 3.

\section{4) Compressor performance}

Compressor performance are shown in Table 4.

5) Capital Cost

The capital cost estimation are shown in Figure 7.

\section{6) Potential loss of production}

The activities that could potentially cause loss of production are shown in Table 5.

\section{7) Operational Cost}

Operational cost estimation are shown in Figure 8.

\section{8) Reservoir}

The reservoir review are shown in Table 6.

\section{9) Installation}

Table 7, the data obtained will then be used as guidelines by experts to give weight to pairwise comparisons. the weighting value is based on the thomas saaty scale shown in the Figure 9.

\section{RESULT}

There are three dominant criteria, namely reservoir $34.0 \%$, technology $27.9 \%$ and potential loss of production $16.2 \%$. These criteria are considered important by experts because the SP well production target by management is to be able to meet the production targets agreed with the government. So that consideration of maintaining well life time, maintaining production stability is a more important priority for the development of SP well production by maintaining the stability of SP well production and the well life reservoir time, profit will be obtained. Capital, operational and safety costs are also important aspects that the company continues to consider for its sustainability.

The results of the selection of alternative operating modes are high low pressure operating modes with a percentage 
The $6^{\text {th }}$ International Seminar on Science and Technology (ISST) 2020

July $25^{\text {th }}$ 2020, Institut Teknologi Sepuluh Nopember, Surabaya, Indonesia

Table 8.

Result of pairwise comparison

\begin{tabular}{|c|c|c|c|}
\hline Level 1 & Level 2 & A.lts & Prty \\
\hline \multirow{16}{*}{ Tectmology (L: .279) } & \multirow{4}{*}{ Maintenance Level IL: .065) } & Low dressure mo & .006 \\
\hline & & Medium pressure & .002 \\
\hline & & High pressure m & .009 \\
\hline & & Hiah low pressu & .005 \\
\hline & \multirow{4}{*}{ Desian [L: .384] } & Low pressure mo & .013 \\
\hline & & Medium pressure & .032 \\
\hline & & High pressure m & .007 \\
\hline & & Hiah low pressu & .053 \\
\hline & \multirow{4}{*}{ Material readiness for com bine anot. } & Low pressure mo & .007 \\
\hline & & Medium pressure & .016 \\
\hline & & Hiah pressure m & .034 \\
\hline & & Hiah low pressu & .049 \\
\hline & & Low pressure mo & .028 \\
\hline & & Medium pressure & .019 \\
\hline & Compressor performance IL: .2001 & High pressure m & .008 \\
\hline & & Hiah low pressu & .023 \\
\hline \multirow{4}{*}{ Capital Cost IL: .092) } & & Low pressure mo & .021 \\
\hline & & Medium pressure & .009 \\
\hline & & Hiah pressure m & .046 \\
\hline & & High low pressu & .007 \\
\hline \multirow{4}{*}{ Potential lost production (L: . 162) } & & Low pressure mo & .008 \\
\hline & & Medium pressure & .017 \\
\hline & & Hiah pressure m & .037 \\
\hline & & High low pressu & .081 \\
\hline \multirow{4}{*}{ Operational Cost [L: .094] } & & Low pressure mo & .014 \\
\hline & & Medium pressure & .003 \\
\hline & & Hiah pressure m & .047 \\
\hline & & Hiah low pressu & .010 \\
\hline \multirow{4}{*}{ Reservoar IL: .340] } & & Low pressure mo & .170 \\
\hline & & Medium pressure & .062 \\
\hline & & Hiah pressure m & .028 \\
\hline & & High low pressu & .096 \\
\hline \multirow{12}{*}{ Installation [L: .033) } & \multirow{4}{*}{ HSSE IL: .540) } & Low pressure mo & .003 \\
\hline & & Medium pressure & .001 \\
\hline & & Hiah oressure m & .009 \\
\hline & & High low pressu & .001 \\
\hline & \multirow{4}{*}{ Time IL: .163) } & Low pressure mo & .003 \\
\hline & & Medium pressure & .001 \\
\hline & & High pressure m & .003 \\
\hline & & Hiah low pressu & .001 \\
\hline & \multirow{4}{*}{ Shutdown Tie in IL: . 297) } & Low pressure mo & .002 \\
\hline & & Medium pressure & .002 \\
\hline & & High pressure m & .005 \\
\hline & & High low pressu & .002 \\
\hline
\end{tabular}

Synthesis with respect to:

Mode of production operation as a strategy to develop SP Wells on the B flowstation

Overal Inconsistency $=.06$

\begin{abstract}
Low pressure mode operation $\quad .275$
Medium pressure mode operation

High pressure mode operation

High low pressure mode operation
\end{abstract}

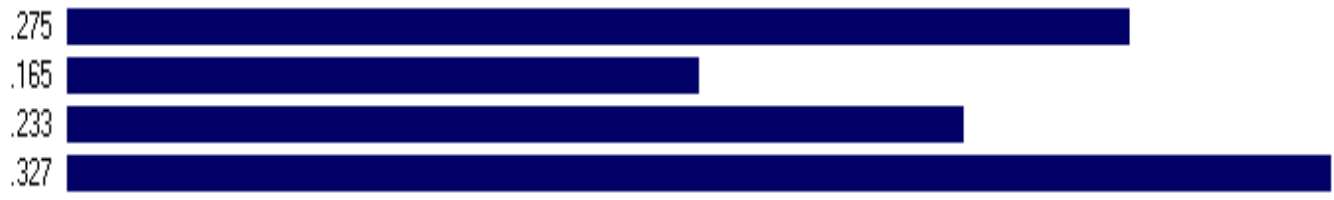

Figure 10. Alternative ranking.

value of $32.7 \%$ with a $C R$ value of 0.06 which means the results are consistent shown in Table 8 and Figure 10. The results of the selected alternative sensitivity tests are high low pressure operating mode which is not sensitive to changes in eigenvector technology, potential loss of production, reservoir and installation. This indicates that the decision of the high low pressure operating mode will not be affected by changes in the input values of these criteria. The highpressure operating mode is very sensitive to capital costs and operational costs. Eigenvector changes in $25 \%$ of the selected alternatives change to high pressure operating mode. Making the decision to use the high pressure operating mode is very relevant if the development of SP wells is only oriented to low investment costs and low operating costs and work can be carried out safely regardless of production issues that have an impact on the stability of SP well production and reservoir life time.

\section{CONCLUSION}

The results of the research on "SP Well Development Strategy in the Offshore B Flowstation Platform Using Analytical Hierarchy Process Method" produced several conclusions as follows: 
The $6^{\text {th }}$ International Seminar on Science and Technology (ISST) 2020

July $25^{\text {th }} 2020$, Institut Teknologi Sepuluh Nopember, Surabaya, Indonesia

The SP well development strategy will be based on the high low pressure operating mode as the chosen alternative with a value of $32.7 \%$.

Reservoir criteria $30 \%$, technology $27.5 \%$, and potential production losses of $16.2 \%$ become the dominant criteria and play an important role in determining alternative modes of operation of SP well production.

Consideration to maintain the stability of SP well production, well life time and designs that are able to accommodate SP well production until it runs out are prioritized because it is in line with the management program to meet the country's gas production. In addition, by maintaining stable profit production, it will be easier to obtain.

The implementation of the AHP method in the SP well development strategy on the offshore platform B flowstation proves that the approach used can be rationally accepted

\section{REFERENCES}

[1] U. Ciptomulyono, "Integrasi Metode Delphi dan Prosedur Analisis Hierarkhis (AHP) Untuk Identifikasi dan Penetapan Prioritas Objektif/Kriteria Keputusan," Majalah IPTEK, pp. 42-51, 2001.
[2] U. Ciptomulyono, "Fuzzy Goal Programming Approach for Deriving Priority Weights in the Analytical Hierarchy Process (AHP) Method," Journal of Applied Sciences Research, pp. 171-177, 2008.

[3] T. L. Saaty, "Decision Making with the Analytic Hierarchy Process," International Journal Services Sciences, pp. 83-97, 2008.

[4] T. Herawan, "Landasan Teori," Fakultas Teknik Universitas Widyatama, Bandung, 2012.

[5] BUMI, Membuka Harapan Baru dari Skema Gross Split dalam Buletin SKK Migas, 46 ed., H. Setyadi, Ed., Jakarta: SKK Migas, 2017, pp. 15.

[6] K. L. Na, "An expert knowledge based decommissioning alternative selection system for fixed oil and gas assets in the South China Sea," Ocean Engineering, pp. 1-11, 2016.

[7] S. Vaisanen, "Using a multi-method approach for decision-making about a sustainable local distributed energy system: A case study from Finland," Journal of Cleaner Production, pp. 1-9, 2016.

[8] N. Bhushan and K. Rai, Strategic Decision Making Applying the Analytic Hierarchy Process, Bangalore: Springer, 2004, pp. 15-20.

[9] S. D. Rahmawati, "Integrated field operation and optimization," Journal of Petroleum Science and Engineering, pp. 1-9, 2012.

[10] T. L. Saaty and L. G. Vargas, "Models, Methods, Concepts \& Applications of the Analytic Hierarchy Process," in International Series in Operations Research \& Management Science, vol. 175, New York, Springer, 2012, pp. 1-129.

[11] B. A. Akash, "Multi-Criteria selection of electric power plant using analytic hierarchy process," Journal of Electric Power System Research, pp. 1-7, 1999.

[12] J. Rahardjo, "Penerapan Multi-Criteria Decision Making dalam pengambilan keputusan sistem perawatan," Jurnal Teknik Industri, p. 3, 2000 . 